\title{
Adsorption Analysis of Activated Carbon from Rice Husk and Kepok Banana (Saba Banana) Peel for Treating Ogan River Water
}

\author{
Kiagus Ahmad Roni a,1,* Erna Yuliwati a,2 \\ ${ }^{a}$ Department of Chemical Engineering, Faculty of Engineering, Universitas Muhammadiyah Palembang, Jendral Ahmad \\ Yani 13 street, ulu, Palembang, 30263, Indonesia \\ ${ }^{1}$ kiagusaroni@gmail.com*,2 erna_yuliwati@um-palembang.ac.id
}

\section{ARTICLE INFO}

Article history

Received October 21, 2020

Revised February 24, 2021

Accepted March 03, 2021

Keywords

Activated Carbon

Adsorption

Kepok Banana Peels

Rice Husk

The Ogan River

\begin{abstract}
Ogan river has been utilized as source of raw water for various purposes. The quality of water needs to be monitored continuously. Nowadays, the Ogan River was polluted by household waste and industrial wastewater. This study aims to obtain a better adsorber of rice husks or kepok banana peels activated carbon for treating the Ogan river. Activated carbon is used in different states of applications after its discovery as a robust and reliable is adsorbent. The used method to produces activated carbon is pyrolysis, physical-chemical activation, and steam pyrolysis from agricultural waste materials, e.g., rice husk, palm oil shell, and banana peels. Activated carbon is applied in water treatment, significantly to reduce total suspended solids, $\mathrm{pH}$, and heavy metal (iron) of the Ogan river. In this study, rice husk and kepok banana peels activated carbon were produced using chemical activation with $\mathrm{H}_{3} \mathrm{PO}_{4} 0.1 \mathrm{~N} 20 \%$ at a temperature of $450^{\circ} \mathrm{C}$. The morphological and performance test was conducted on prepared activated carbon. The top surface area of both activated carbon was observed using a scanning electron microscope (SEM) and Fourier-transform infrared spectroscopy (FTIR) analysis. The mean pore size was calculated to describe the adsorption process of the ogan river, which indicated total suspended solids (TSS) and iron (Fe) concentration, then $\mathrm{pH}$ value. The results showed that kepok banana peels activated carbon reduced TSS levels of 79.3 to $48.2 \mathrm{mg} / \mathrm{L}$, decreased Fe concentration of 0.63 to $0.07 \mathrm{mg} / \mathrm{L}$, and increased $\mathrm{pH}$ value of 5.94 to 7.89. Meanwhile, the adsorption using activated carbon of rice husk could reduce TSS concentration of 79.3 to $36.1 \mathrm{mg} / \mathrm{L}$, decrease $\mathrm{Fe}$ concentration of 0.63 to $0.01 \mathrm{mg} / L$ and increase the $\mathrm{pH}$ value increased from 5.94 to 7.16. It was concluded that the activated carbon of rice husks has better performance than kepok banana peels.
\end{abstract}

This is an open-access article under the CC-BY-SA license.

\section{Introduction}

The first activated carbon production plant was built in Germany purposely for a sugar refining industry. Lately, some of the plants emerged to produce activated carbon for water and wastewater treatment processes. Recently, activated carbon is abundantly utilized as an air purifier, food, pharmaceutical products, and advanced water and wastewater treatment [1]. Many previous works presented activated carbon regarding its production, characteristics, and possible applications [1-3]. Regarding activated carbon for treating water sources, lakes, swamps, few researchers have also been developed the raw material to minimize the organic waste and production cost [3-5].

Ogan River is one of the three longest rivers and many potential river in South Sumatera. The use of river water as raw water for various services, needs to be maintained and monitored the water quality conditions continuously. At present, the Ogan river was polluted by household waste and industrial wastewater and affected public health the number of residents around the river [1]. This 
situation needs more attention to reclamation this water source. Moreover, based on the regulation of Republic Indonesia Number 82, 2001 about water quality standards include in the river, swamp, lake, dam as tabulated in Table 1 [2].

Table 1. Composition of Ogan River and water standard

\begin{tabular}{cccc}
\hline Component & Unit & Ogan River & Water Quality Std \\
\hline Physical & & & \\
\hline Dissolved Oxygen & $\mathrm{mg} / \mathrm{L}$ & $3.00 \pm 0.12$ & 3 \\
TSS & $\mathrm{mg} / \mathrm{L}$ & $79.3 \pm 0.21$ & 119.25 \\
Turbidity & $\mathrm{NTU}$ & $13.87 \pm 0.23$ & 9.0 \\
pH & - & $5.94 \pm 0.84$ & $6-9$ \\
Temperature & ${ }^{\mathrm{C}}$ & $28.50 \pm 1.45$ & 27 \\
\hline Chemical & & & 0.3 \\
\hline Iron $(\mathrm{Fe})$ & $\mathrm{mg} / \mathrm{L}$ & $0.63 \pm 1.01$ & 0.03 \\
Free Chloride & $\mathrm{mg} / \mathrm{L}$ & $0.36 \pm 0.22$ & 0.1 \\
Mangan $(\mathrm{Mn})$ & $\mathrm{mg} / \mathrm{L}$ & $0.00 \pm 1.08$ & 10 \\
Nitrit $\left(\mathrm{NO}_{3}\right)$ & $\mathrm{mg} / \mathrm{L}$ & $12 \pm 0.92$ & \\
\hline
\end{tabular}

Table 1 showed the physical and chemical components in the Ogan river and the water quality standard. It described that the Ogan river was polluted by waste and had to reclamation to remove various pollutants. It is also being investigated as an adsorbent from agricultural waste for removing various contaminants from water and wastewater [5].

Nowadays, the development of adsorption using activated carbon has attracted significant attention in industrial water or wastewater treatment. It has been successfully implemented in many sectors, such as water reclamation. Many studies have been documented on the use of activated carbon for adsorption processing for treating water. These studies used organic and inorganic materials such as agricultural waste, namely, rice husk, palm oil shell, coconut shell, banana peel, and durian peel [6,7]. Bananas (Musa acuminata, AAA Group) are among the most important fruit crops with a global annual production that surpassed 100 million tons in 2011 [6]. Bananas are mostly consumed raw, and their processed products include banana flour, chips, and puree. Banana peels constitute about $30 \%$ of the fruit and represent an environmental problem because of their large nitrogen and phosphorus and high water content [7]. The use of banana peels as a source of high-value compounds such as cellulose, phenolic compounds is exciting not only from an economic value of view but also from an environmental perspective.

Rice (Oryza sativa) husk is the waste material produced during rice processing. Approximately 10 $\mathrm{kg}$ of rice husk is produced when processing $50 \mathrm{~kg}$ of paddy. Rice husk is a relatively abundant and inexpensive material. It is currently being developed as an adsorbent for removing various pollutants, such as dyes, phenols, organic compounds, pesticides, inorganic anions, and heavy metals can be removed very effectively [8]. Studies on the adsorption of various pollutants by rice husk materials are reviewed and the adsorption mechanism [9]. In this study, rice husks and kepok banana peels were used as an adsorbent for treating the Ogan river, as shown in Fig.1. Adsorbents made in lab-scale in varied composition and contact time, and it has an amorphous structure that is important in the adsorption process.

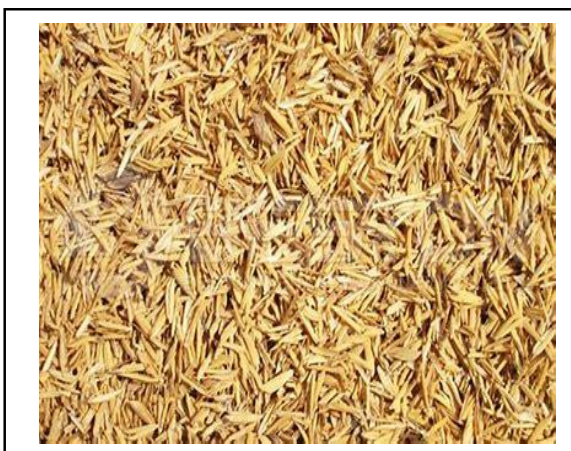

(a)

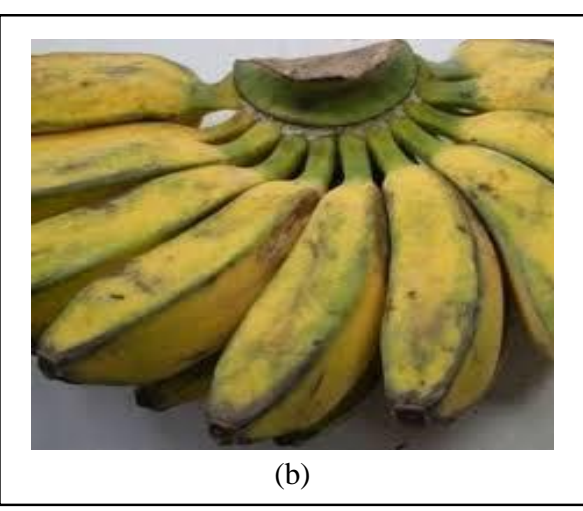

(b)

Fig. 1.Raw Material of (a) Rice Husk and (b) Kepok Banana Peel 
Rice husk and kepok banana peels were carbonized and activated using an acid solution to prepare activated carbon with a large mean pore diameter [8]. Table 2 showed both raw materials' composition, that content cellulose as an essential component in producing activated carbon.

Table 2. Composition of rice husk and kepok banana peels

\begin{tabular}{ccc}
\hline Component & Content of Rice Husk $(\mathbf{g} / \mathbf{1 0 0 g})$ & Content of Kepok banana peels $(\mathbf{g} / \mathbf{1 0 0} \mathbf{g})$ \\
\hline$\alpha$ - Cellulose & $31.13 \pm 2.13$ & $40.24 \pm 2.78$ \\
Hemicellulose & $22.48 \pm 0.98$ & $20.25 \pm 2.91$ \\
Lignin & $22.34 \pm 1.34$ & $16.58 \pm 2.76$ \\
Mineral Ashes & $13.87 \pm 0.23$ & $11.50 \pm 0.11$ \\
Extractives & $2.33 \pm 2.34$ & $4.34 \pm 2.45$ \\
Moisture & $7.86 \pm 1.09$ & $8.23 \pm 1.67$ \\
\hline
\end{tabular}

Activated carbon is the most potent adsorbents known, and a form of carbon processed to have small, low-volume pores that increase the surface area for adsorption or chemical reactions. A characteristic feature is its porous structure and the resulting immense surface area. Due to its exceptional adsorption qualities, activated carbon is widely used in a process destined to purify efficiency. Activated carbon works on the principle of adsorption that involves collecting solute components on the surface of adsorbent solids. This phenomenon is associated with physically attractive forces that bind solute molecules, commonly known as Van der Waals force. Adsorption is a physical process. The substance adsorbed on the solid does not undergo any chemical reaction. The adsorbing solid is referred to as adsorbent, and the substance to be adsorbed from a liquid as the solute. The adsorption power and rate are determined by the type of activated carbon, the particle size, the mean pore size, and its distribution [9].

The $\mathrm{pH}$ values, total suspended solids, and iron concentration were analyzed, respectively. Iron is dissolved as a ferric salt $(\mathrm{Fe} 3+)$ or ferrous salt $(\mathrm{Fe} 2+)$; suspended as colloidal grains $(<1 \mathrm{~mm}$ diameter) or larger, e.g., $\mathrm{Fe}(\mathrm{OH})_{3}$; and combined with organic substances or solid inorganic substances (such as clay and fine particles dispersed) [10]. Iron (Fe) is an essential microelement for the body, especially needed in hematopoiesis (blood formation), namely in the synthesis of hemoglobin [11]. This phenomenon tends to determine the impact of Fe on biological, physical, and components chemistry, especially in sediment and water.

In this study, the activated carbon of rice husk and kepok banana peels have been fabricated by adding $0.1 \mathrm{~N} \mathrm{H}_{3} \mathrm{PO}_{4}$ to increase its performance. Mean pore size expressed in terms of the contact area to measure the tendency for the surface adsorbent. The surface structures were studied using a scanning electron microscope (SEM), and elemental composition analysis of the sample activated carbon was investigated using FTIR apparatus. The activated carbon performance was characterized by $\mathrm{pH}$ values, total suspended solids (TSS), and iron concentration removal efficiency for treating the ogan water.

\section{Research Methodology}

\subsection{Materials}

The used materials were rice husks from Talang root village Pali District, kepok banana peels from Prabumulih City, the water of Ogan River from Tanjung Raja Village, and phosphoric acid solution $0.1 \mathrm{~N}\left(\mathrm{H}_{3} \mathrm{PO}_{4}\right)(85 \%$ w/w Merck-Sigma Aldrich, Germany).

\subsection{Preparation of activated carbons}

Activated carbon of rice husk and kepok banana peels was prepared with few steps, as illustrated in Fig. 2. The activated carbon was designed in three stages, namely preparation, carbonization, and activation. The first step is preparing; $1500 \mathrm{~g}$ of rice husk and $1500 \mathrm{~g}$ of kepok banana peels were chopped and dried for one day. The reducing effort was made to provide pores of kepok banana skin. The second step is carbonization. As much as $1500 \mathrm{~g}$ of rice husks and $1500 \mathrm{~g}$ of kepok banana peel were covered with aluminum foil and then put into the furnace at a temperature of 400 and $450{ }^{\circ} \mathrm{C}$ for 50 minutes, then cooled at room temperature naturally. It was grinded and sieved on size of 35 mesh. The third step was the activation stage that the varied amount of 10,20, and $30 \mathrm{~g}$ carbon of rice husk carbon and kepok banana peels are activated using $0.1 \mathrm{~N} \mathrm{H}_{3} \mathrm{PO}_{4}$ and then stirred for 10 minutes and 
kept it for 24 hours. The mixture was filtered and washed with aquadest until neutral ( $\mathrm{pH}$ of 7). Finally, the carbon was dried at $117^{\circ} \mathrm{C}$ and cooled at room temperature for 1-2 days.

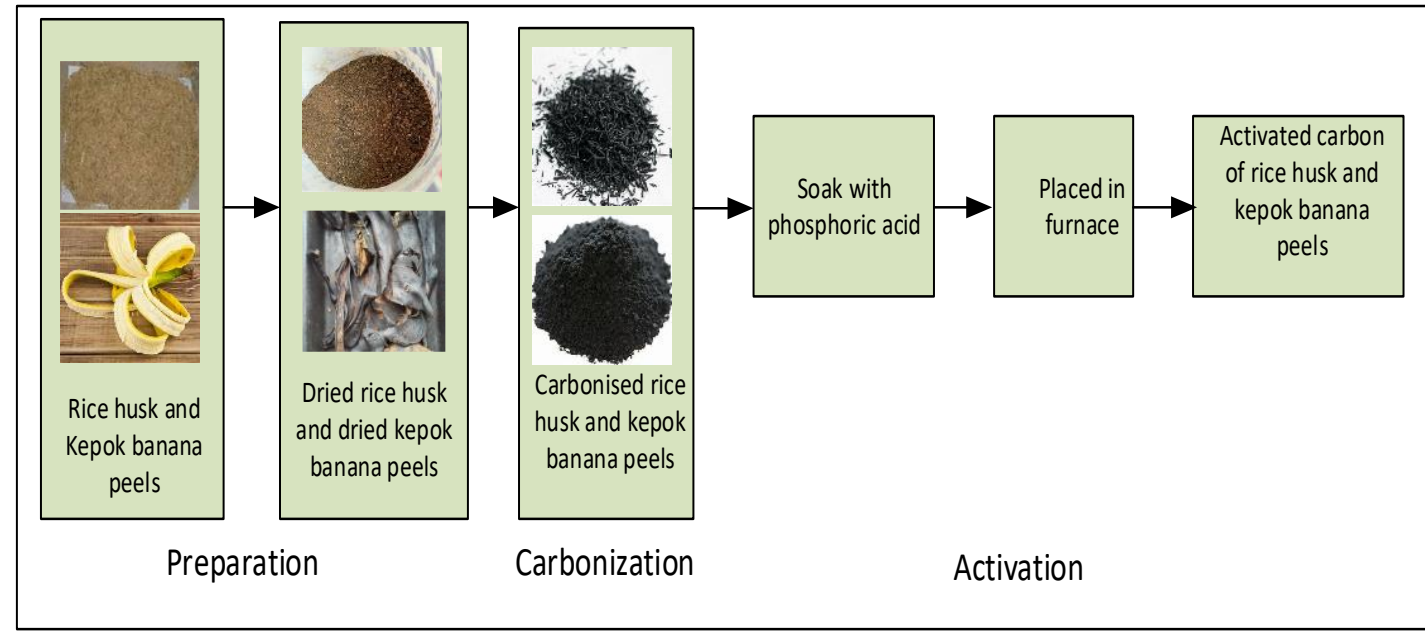

Fig. 2.Schematic diagram of activated carbon of rice husk and kepok banana peels production

\subsection{Factors affecting activated carbon production}

\section{1) Temperature}

In the activated carbon production, temperature plays an essential role in affecting the produced activated carbon's character. Several studies have been reported that activation temperature has a significant influence on providing surface area [12-14]. The temperature range of 400 and $500{ }^{\circ} \mathrm{C}$ was reported by previous researchers to be considered regardless of the time taken and the impregnation ratio for a variety of raw materials. Therefore, increasing activation temperature decreases activated carbon yield during production and increases the volume of volatile substances released. In this study, the temperature of activation has been taken at 400 and $450{ }^{\circ} \mathrm{C}$.

\section{2) Activation time}

The activation time has a more significant effect on the carbonization of both carbon materials. Bae et al. [13] observed that as excessive activation time occurs, it causes a reduction in product yield. Also, the activation time might be attributed to the volatilization of organic substances from rice husk and kepok banana peels [14].

\subsection{Activated carbon characterization}

\section{1) Moisture Content}

Activated carbon could be analyzed by determining the moisture content. As much as 10 grams of activated carbon are placed on a porcelain plate. The sample was dried in an oven at 104 to $110{ }^{\circ} \mathrm{C}$ for 1 hour until the weight was constant and cooled in a desiccator for about 20 minutes and then weighed. The equation of moisture content was described as follows,

Moisture content $(\%)=\frac{(a-b)}{a} \times 100 \%$

$\mathrm{a}$ is the weight of the sample before heating $(\mathrm{g})$, and $\mathrm{b}$ is the sample's weight after heating $(\mathrm{g})$.

\section{2) Ash Content}

Ash content was determined by weighing 10 grams of activated carbon and putting in the cup, then quickly covering it with the aluminum foil. The activated carbon was put into the cold muffle furnace set up at a temperature of 450 and $500{ }^{\circ} \mathrm{C}$ and dried for 1 hour. After drying for 1 hour, the furnace's temperature was increased from 700 to $750{ }^{\circ} \mathrm{C}$ and then activated carbon was continue dried for 2 hours or until the activated carbon becomes ash entirely. The cup was removed from the furnace and then presses down on the metal plate. It was cooled for 10 minutes and put into a desiccator, then weighed. The ash content could be calculated with the following equation.

$$
\text { Ash content }(\%)=\frac{\left(m_{3}-m_{1}\right)}{\left(m_{2}-m_{1}\right)} \times 100 \%
$$


Where $m_{1}$ is the weight of the empty plate, $m_{2}$ is the weight of container and sample, and $m_{3}$ is the plate and ash weight.

The moisture content of rice husks and kepok banana peels activated carbon were analyzed to determine its hygroscopic properties. Increasing the surface area of activated carbon will improve hygroscopic properties caused by absorbed water from the air by activated carbon.

\section{3) Scanning Electron Microscope Analysis}

The morphology of activated carbons was analyzed using a scanning electron microscope (SEM, S-800M, Hitachi High Technology. Co. Ltd., Tokyo, Japan). Samples were frozen in liquid nitrogen and then submitted to facture. All samples were sputter-coated with a thin gold film before SEM observation at magnification $9 \mathrm{k}$.

4) Fourier-Transform Infrared Analysis

Fourier transform infrared spectroscopy (FTIR) is a technique used to obtain the infrared spectrum of absorption, emission, and photoconductivity of solid, liquid, and gas. FTIR analysis measures a sample of both activated carbon's of infrared light at various wavelengths to determine the materials' molecular composition and structure.

\subsection{Adsorption Performance of Ogan River}

Activated carbon of rice husk and kepok banana peels as adsorbents were used to treat the ogan river completely. The measurement of $\mathrm{pH}$ value, total suspended solids (TSS), and heavy metal, e.g., iron $(\mathrm{Fe})$, were done three times to avoid data errors and get consistent results. The equations were provided for all parameters, respectively.

\section{1) $\mathrm{pH}$ measurement}

It is well known that the difference in $\mathrm{pH}$ values is a significant physical component. $\mathrm{pH}$ is a measure of the water's hydrogen ion concentration as ranked on a scale of 1.0 to 14.0. The lower the $\mathrm{pH}$ of water, the most acidic it is. The higher $\mathrm{pH}$ value tends to more basic or alkaline. Alkalinity was measured using digital $\mathrm{pH}$-meter water tester HI98128 (Hanna Instruments, Inc, USA). These values should fulfill the regulation of water quality standards, as shown in Table 1.

\section{2) Total Suspended Solid (TSS) measurement}

The TSS measurement is used to control various treatment processes and examine water and wastewater quality, mostly water of the ogan river. The level of suspended solids in water and wastewater affects the water quality and how it can be used. TSS is measured in laboratories using the standard ASTM D5907-18 (Thermofisher, Thermo scientific, Singapore). These test methods cover the determination of the filterable matter, total dissolved solids (TDS) and non-filterable matter, total suspended solids (TSS) in drinking, surface and saline water, domestic and industrial wastes. The equations below could use to calculate the concentration of total suspended solids removal.

$$
\text { TSS removal }(\%)=\frac{\left(T S S_{0}-T S S_{1}\right)}{\left(T S S_{0}\right)} \times 100 \%
$$

where $\mathrm{TSS}_{0}$ is initiate concentration of TSS insample before adsorption, $\mathrm{TSS}_{1}$ is the TSS concentration after adsorbing.

3) Iron $(\mathrm{Fe})$ measurement

Iron concentration was measured the iron content of river water after treating with activated carbon. The iron analysis was carried out using an atomic absorption spectrophotometer using ASTM D1068-77 to result in accurate values.

$$
\text { Iron removal }(\%)=\frac{\left(F e_{0}-F e_{1}\right)}{\left(F e_{0}\right)} \times 100 \%
$$

where $\mathrm{Fe}_{0}$ is initiate concentration of $\mathrm{Fe}$ in sample before adsorption, $\mathrm{Fe}_{1}$ is the TSS concentration after adsorbing. 


\section{Results and Discussion}

\subsection{Morphological studies of activated carbons}

The activated carbons were fabricated using a chemical activation method with varied temperature and constant activated time. The morphological of activated carbons were studied by SEM that illustrated in Figure 3.

\section{1) Scanning electron microscope images}

Figure 3 shows the SEM images of the activated carbon of rice husk and kepok banana that carbonized at temperature $450{ }^{\circ} \mathrm{C}$ for 2 hours of activated time. Figure 3 (a) and (b) showed the surface morphology of both activated carbon obtained using a scanning electron microscope with magnification $9 \mathrm{k}$ for each sample. It showed the form of spherical shape with the size of the pores distributed well on the surface of both activated carbon. In image analysis of SEM, photos show the shape of particles to form pieces of size. The size of pieces increases significantly in kepok banana peels activated carbon. Meanwhile, the activated carbon of rice husk has a porous structure with cracks and crevices.
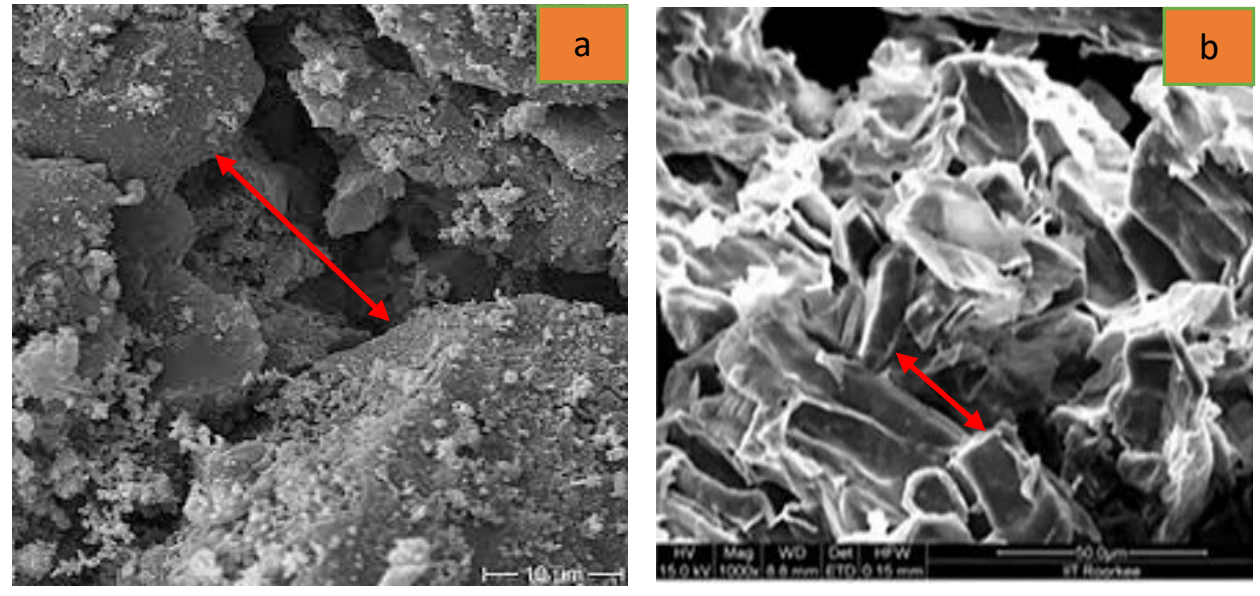

Fig. 3.SEM of (a) rice husk, (b) kepok banana peels activated carbon

\section{2) Surface functional groups analysis}

Figure 4 shows the surface functional groups of prepared activated carbon of rice husk and kepok banana peels. FTIR spectra for activated carbon of rice husk were presented in the following figure.

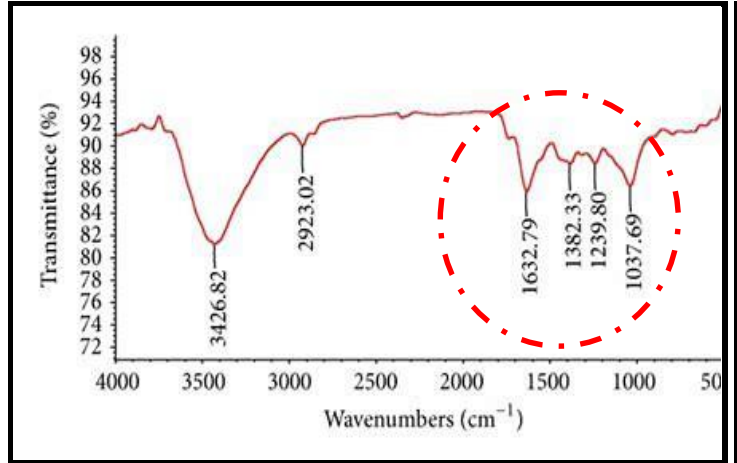

(a)

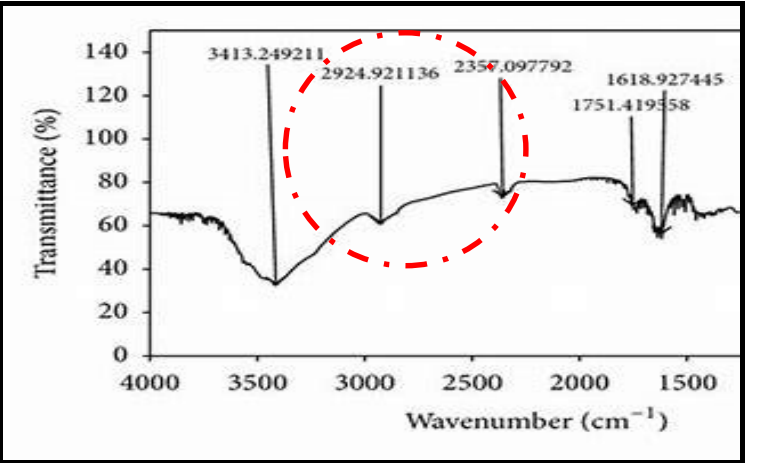

(b)

Fig. 4.FTIR spectra of (a) rice husk, (b) kepok banana peels activated carbon

In figure 4, FTIR of kepok banana peels activated carbon showed the most polar surface, functional groups. These groups were not present in kepok banana peels activated carbon, while it was apparent that the spectra of both activated carbon samples have similar vibration bands. The total acidic groups decrease gradually with increasing activation temperature, whereas these phenomena have not been observed for the whole basic groups. This result can be explained by the decomposition of the surface functional groups at a $450{ }^{\circ} \mathrm{C}$. The weak peaks at around $2300 \mathrm{~cm}^{-1}$ generally indicate the presence of symmetric or asymmetric aliphatic vibration bands. The wide $-\mathrm{OH}$ peaks at $3300-3400 \mathrm{~cm}^{-1}$ indicate alcohol, phenol, and carboxylic acids, and the asymmetric and symmetric C-H vibrations at 2950- 
$2800 \mathrm{~cm}^{-1}$ indicates the presence of aliphatic structures. Broadband located about $3400 \mathrm{~cm}^{-1}$ is attributed to O-H hydroxyl groups. The peaks around $1750-1600 \mathrm{~cm}^{-1}$ are the result of the $\mathrm{C}=\mathrm{C}$ and $\mathrm{C}=\mathrm{O}$ vibrations present in the aromatic structure, and around $1480-1360 \mathrm{~cm}^{-1}$ are the result of the $\mathrm{C}-$ $\mathrm{H}$ bonds $[15,16]$. This indicates the formation of carbonyl-containing groups and the initial aromatization of the precursor. However, these two bands' intensities show that the aromatization extent and the content of carbonyl-containing groups are shallow at this point.

The acidic groups (carboxylic, lactonic, and phenolic) decompose at $100-400{ }^{\circ} \mathrm{C}$, lower than those It found in activated carbon of rice husk the $-\mathrm{OH}$ and $\mathrm{Si}-\mathrm{OH}$ bend at wave number $3426.82 \mathrm{~cm}^{-1}$, which showed the OH stretch in hydroxyl group and wavenumber of $2923.02 \mathrm{~cm}^{-1}$ (the spectra of nonpolar functional groups), which led C-H asymmetric/symmetric in the aliphatic compound and $\mathrm{N}-\mathrm{H}$ bands [17]. On the other hand, kepok banana peels' activated carbon has a wavenumber of 3413.25 $\mathrm{cm}^{-1}$ and wavenumber of $2924.92 \mathrm{~cm}^{-1}$, which C-H asymmetric/symmetric in the aliphatic compound and wavenumber of $2357.09 \mathrm{~cm}^{-1}$ showed the $-\mathrm{NH}$ stretch in amine, showed the polar surface functional. Non-polar surface functional groups will make easier adsorption onto activated carbon, whereas polar surface functional groups will inhibit activated carbon's adsorption capacity.

\subsection{Structural studies of activated carbons}

The structure of activated carbons was identified by moisture content, ash content, and mean pore size surface, as showed in Table 3. The mean pore size of both activated carbon was measured using the same tools and viewed in the images, respectively. Activated carbon of rice husk has a mean pore diameter of $1.56 \mu \mathrm{m}$, and kepok banana peels have a mean pore diameter of $1.12 \mu \mathrm{m}$. Due to the higher mean pore size, increasing the uptake for higher relative pressure in the risk husk activated carbon. At lower pressure, the pores are filled, the region at moderate forces indicates multilayer adsorption inside the pores, and an increase at high pressure means capillary condensation in the pores.

Table 3. Structural of rice husk and kepok banana peels activated carbon

\begin{tabular}{cccccc}
\hline \multirow{2}{*}{ Component } & Unit & \multicolumn{4}{c}{ Activated carbon of (s.d) } \\
\cline { 3 - 6 } & & \multicolumn{3}{c}{ Rice husk } & \multicolumn{2}{c}{ Kepok banana peels } \\
\hline Activated temperature & ${ }^{\circ} \mathrm{C}$ & 400 & 450 & 400 & 450 \\
\hline & & Physical and chemical & & \\
\hline Fixed carbon & $\%$ & 68.90 & 69.82 & 65.08 & 3.65 \\
Avg. Moisture content & $\%$ & 4.32 & 4.01 & 4.46 & 5.02 \\
Avg. Ash content & $\%$ & 5.13 & 4.01 & 5.43 & 1.12 \\
Mean pore size & $\mu \mathrm{m}$ & 1.43 & 1.56 & 1.01 & 43.28 \\
Yield & $\%$ & 45.92 & 47.92 & 39.91 & \\
\hline
\end{tabular}

\subsection{Adsorption performance}

1) Effect of surface properties on adsorption

The effect of activated carbon characterization parameters on adsorption was investigated using activated carbon of rice husk and kepok banana peels. As shown in Table. 4, Activated carbon of rice husk showed the maximum value of $\mathrm{pH}$, TSS removal, and iron removal by using activated carbon with a carbonization temperature of $450{ }^{\circ} \mathrm{C}$. The values were demonstrated a similar trend to the parameters, showing the maximum value of $\mathrm{pH}$ of 7.14 , TSS content of $36.1 \mathrm{mg} / \mathrm{L}$, and iron content of $0.01 \mathrm{mg} / \mathrm{L}$. The adsorption of kepok banana peel activated carbon shows lower performance than rice husk activated carbon.

Table 4. Adsorption performance for treating water of Ogan river

\begin{tabular}{cccc}
\hline Parameter & $\begin{array}{c}\text { The water source of } \\
\text { Ogan Ilir }\end{array}$ & \multicolumn{2}{c}{ Activated carbon of } \\
\cline { 3 - 4 } & 5.94 & $7.14(20 \%)$ & Kepok banana peel \\
\hline $\mathrm{pH}$ & 79.3 & $36.1(54.48 \%)$ & $6.75(13.64 \%)$ \\
TSS content, $\mathrm{mg} / \mathrm{L}$ & 0.63 & $0.01(98.41 \%)$ & $48.2(39.21 \%)$ \\
Fe content, $\mathrm{mg} / \mathrm{L}$ & & & $0.07(88.89 \%)$ \\
\hline
\end{tabular}

The $\mathrm{pH}$ value of water from the ogan river increase $13.64 \%$, this caused by the composition of activated carbon in rice husks, and kepok banana peels have been able to neutralize river water. It can be seen that the activated carbon of both materials could increase the $\mathrm{pH}$ value and reached the water quality standards [2]. $\mathrm{pH}$ value affects the ability of the active side of the mass and metal ion 
adsorption mechanism. The dependence of metal ion adsorption on $\mathrm{pH}$ is closely related to the functional groups present on the surface of the mass and metal ions in the solution [18].

The total suspended solids value decrease after adsorbing using both activated carbons. TSS content has a close relationship with water transparency. The presence of solids usually hinders the penetration of light that enters the waters. This related the relationship with TSS and brightness is biased inversely. It was shown that the decrease of TSS content in the ogan river water was caused by adsorption that using both activated carbons. The activated carbon of rice husk and kepok banana peels resulted in TSS removal of $54.48 \%$ and $39.21 \%$, respectively. This change was reached because of the activated carbon composition, which has high fixed carbon composition. Based on the structural-functional groups' analysis, $\mathrm{C}-\mathrm{H}$ asymmetric/symmetric is an aliphatic compound and nonpolar surface functional. Non-polar surface functional groups will make easier adsorption onto activated carbon [17,19]. Moreover, the decreased TSS value makes the water clearer because the suspended solids are near related to the water's turbidity level, so that activated carbon is more effectively used in reducing TSS values.

Results of iron removal using activated carbon of rice husk and kepok banana peels for adsorbing ogan river reach a potential value. Significantly higher iron removals were $98.41 \%$ and $88.89 \%$ using activated carbon of rice husk and kepok banana peels. The adsorption process indicated that both activated carbon had been worked successfully. These values also reflected rice husk and kepok banana peels have been able to use as adsorbents.

\section{Conclusions}

Activated carbon of rice husk and kepok banana peels were prepared using chemical activation with $0.1 \mathrm{~N} \mathrm{H}_{3} \mathrm{PO}_{4}$ at a temperature of $450{ }^{\circ} \mathrm{C}$. Various characterizations and measurement techniques such as activated carbon morphology and structural, mean pore size, adsorption performance were utilized to evaluate fine structural details of the activated carbon structure and adsorption performance. The water of the ogan river was conducted through prepared activated carbon. SEM analysis indicated that activated carbon of rice husk has a large mean pore size of $1.56 \mu \mathrm{m}$ and has a porous structure with cracks and crevices. The composition of activated carbon of both materials affected the potential result of the adsorption performance. $\mathrm{pH}$ value, TSS removal, and iron removal indicated steady performance remarkably. Significantly higher TSS removal of $54.48 \%$, iron removal of $98.41 \%$, and the increase of $\mathrm{pH}$ value of 5.94 to 7.14 were observed. These values also reflected the activated carbon of rice husk resulted in higher performance than activated carbon of kepok banana peels.

\section{Acknowledgment}

The authors acknowledge the understanding and help in terms of e-resources and facilitation given by the Universitas Muhammadiyah Palembang (UMPalembang) while conducting this study.

\section{References}

[1] R. Masayu, "Analisis Kualitas Air Sungai Ogan sebagai Sumber Air Baku Kota Palembang," Jurnal Redoks, vol. 2(1), pp. 48-52, 2017.

[2] R. Irawan, H. S. Robiyanto, R. Moh. Rasyid, "The Analysis of water quality in the Komering River of ulak Jermun village Ogan Komering Ilir District as the basic for aquaculture management with keramba system,” Jurnal Akuakultur Rawa Indonesia, Vol. 5(2), pp. 182-194, 2017.

[3] P. Saueprasearsit, "Adsorption of chromium $\left(\mathrm{Cr}^{+6}\right)$ using durian peel," In: Intl Conf on Biotechnology and Environment Management, Singapore, 18:33-38, 2011.

[4] S. Srikun, S. Hirunpraditkoon, K. Nuithitikul, "Lead adsorption of activated carbon synthesized from durian peel," Adv. Fluid Mechanics Heat. Mass Transf., pp.66-71, 2011.

[5] W. Jonglertjunya, "Biosorption of Lead (II) and Copper (II) from Aqueous," Chiang Mai J. Sci., 35(1), pp.69-81, 2008.

[6] I.S.O. Tulio, F.R. Morsyleide, L.C. Fabio, H.F.P. Paulo, K.M. Graham, W. Nikolaus, E.M. Selma, W.W. Keith, M.C.A. Henriette, "Optimization of pectin extraction from banana peels with citric acid by using response surface methodology," Food Chemistry, Vol. 198, pp. 113-118, 2016. 
[7] M.A. Mohammed, A. Shitu, M.A. Tadda, M. Ngabura, "Utilization of various agricultural waste materials in the treatment of industrial wastewater containing heavy metals: a review," Int. Res. J. Environ. Sci., 3(3), pp.62-71, 2014.

[8] J. Alvarez, G. Lopez, M. Amutio, J. Bilbao, M. Olazar, "Upgrading the rice husk char obtained by flash pyrolysis for the production of amorphous silica and high quality activated carbon," Bioresour. Technol., 170, pp. 132-137, 2014.

[9] M. Ahmaruzzaman and V.K. Gupta, "Rice husk and its ash low-cost adsorbents in water and wastewater treatment," Ind.Eng.Chem.Res, 50(24), pp. 13589-13613, 2011.

[10]H. Ummah, D.A. Suriamihardja, M.Selintung, A.W. Wahab, "Analysis of chemical composition of rice husk used as absorber paltes sea water into clean water," ARPN J. Eng. Appl, Sci, Vol. 10, pp. 6046-6050, 2015.

[11] W. Bae, J. Kim, J. Chung, "Production of granular activated carbon from food-processing wastes (walnut shells and jujube seeds) and its adsorptive properties," J. Air Waste Manage. Assoc., 64(8), pp. 879-886, 2014.

[12]E. Bernard, A. Jimoh, J.O. Odigure, "Heavy metals removal from industrial wastewater by activated carbon prepared from coconut shell," Res. J. Chem. Sci., 3(8), pp.3-9, 2013.

[13] W. Bae, J. Kim, J, Chung, "Production of granular activated carbon from food-processing wastes (walnut shells and jujube seeds) and its adsorptive properties," J. Air. Waste Manage. Assoc., 64(8), pp. 879-886, 2014.

[14]R. Boopathy, S. Karthikeyan, "Adsorption of ammonium ion by coconut shell-activated carbon from aqueous solution: kinetic, isotherm, and thermodynamic studies," Env. Sci Pollut Res., 20, pp.533-542, 2013.

[15] M.M. Rahman, Q.H., Bari, N. Mohammad, A. Ahsan, H.R, Sobuz, M.A, Uddin, "Characterization of rice husk carbon produced through simple technology," Adv. Mater. Sci. Appl., 2(1), pp. 25-30, 2013.

[16] W. Yuanita, "Kualitas Perairan Sungai Musi di Kota Palembang," Sumatera Selatan, Bioeksperimen, , Vol.1(1), 2015.

[17] E.L. Floyd, K. Sapag, J. Oh, C.T. Lungu, "Photothermal desorption of single-walled carbon nanotubes and coconut shell - activated carbons using a continuous light source for application in air sampling," Annals of Occupational Hygiene.;58(7), pp. 877-888, 2014.

[18] R. Shaheed, C.H. Azhari, A. Ahsan, WHMW. Mohtar, "Production and characterisation of low-tech activated carbon from coconut shell," J. Hydrol. Environ. Res., 3(1), pp. 6-14, 2015.

[19] K. Banerjee, S.T. Ramesh, R. Gandhimathi, P.V. Nidheesh, K.S. Bharathi, "A novel agricultural waste adsorbent, watermelon shell for the removal of copper from aqueous solutions," Iran. J. Energy Environ., 3(2), pp. 143-56, 2012. 